\title{
Vékony Vivien
}

\section{Bocsár és társai}

1. A régi magyar településnevek egyik jellegzetes típusa foglalkozást jelentő szavakból alakult. Azokat a névalkotó lexémákat, amelyek népeket, törzseket és foglalkozásokat jelölnek, társadalmi csoportneveknek nevezzük, ugyanis közös jellemzőjük, hogy nominatívuszi alakban is emberek csoportját, emberi közösséget jelölnek (HOFFMANN-RÁCZ-TÓTH 2018: 248). A foglalkozásnévi eredetü településnevek esetében az elsődlegesen egyént jelölő szó a névadás során gyüjtőnévként az egész falu megnevezésévé vált. A településnevekben megjelenő egyes középkori foglalkozásokat a történészek az ún. fejedelmi szolgálónépekhez kötik. A középkorban egy-egy település teljes lakossága vagy csupán lakosainak egy része valamilyen szolgálatra volt kötelezve. A kérdés társadalomtörténeti vonatkozásainak a kutatása a történettudomány feladatkörébe tartozik, amely a szolgáltatást végző lakosokat szolgálónépeknek, a településeket szolgálónépi településeknek nevezi (HECKENAST 1970, GYÖRFFY 1972, KRISTÓ 1976, KIS P. 2010). Nyelv- és névtörténeti szempontból e településnév-típus eddig viszonylag kevesebb figyelmet kapott (vö. RÁCZ A. 2015, HOFFMANN-RÁCZ-TÓTH 2018: 282 290). E kérdéskört legutóbb TÓTH VALÉRIA érintette egyik tanulmányában (2019), amelyben a Taszár és a Csatár településnevek névbokrát vizsgálta meg komplex módon, a helynév-rekonstrukció módszerét alkalmazva, s arra az eredményre jutott, hogy a Taszár típusú helynevek a szlávban keletkezhettek, így a magyarban névátvételek, a Csatár nevek viszont inkább a szlávból átvett köznévből a magyarban alakult helynevek.

Én magam az alábbiakban az ő módszerét alapul véve és némileg kiterjesztve kívánom megvizsgálni a Bocsár településneveket. Az ennek alapjául szolgáló 'hordókészítő' jelentésű bocsár közszót azonban nem önmagában elemzem, hanem a vele nagyjából azonos jelentésü, így egy szómezőbe tartozó lexémákkal együtt. A vizsgálat során ennek megfelelően figyelembe veszem az ugyancsak ómagyar kori adatolású kádár, bodnár és pintér szavakat is. Kiindulásom alapja tehát nem a helynévi előfordulás, hanem a szemantikai azonosság a bizonyos fokú alaki hasonlóság (azonos jellegü szóvégződések) megléte mellett. A vizsgálatot azonban a szómező további elemeire is kiterjesztem, így a fentiekkel lényegében azonos jelentésü kádas és hordós szavakat is bevonom az elemzésbe. 
E módszertani kísérletnek az a célja, hogy megvizsgáljam: a jelenlegi szótörténeti tudásunkhoz képest kapunk-e további tudományos ismereteket a komplex nyelv- és névtörténeti elemzés révén.

2. A bocsár szót KNIEZSA ISTVÁN a kétes eredetü, kihalt szavak között tárgyalja $b u c s a ́ r(d)$ címszó alatt. Első adatát a veszprémvölgyi apácák görög nyelvü

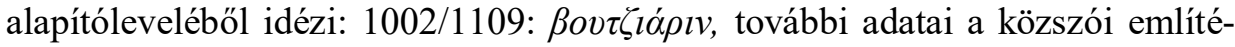
sekre latinizált formák: 1209: buchariorum, 1237-1240: nomina buchariorum, 1280/1323: terram curriferorum, bochariorum reginae stb. (SzlJsz. 600). Magyar nyelvü közszói adatát nem közli, jelentését kérdőjellel 'kádár'-ként rekonstruálja, amely egy Árpád-kori kondicionárius réteget jelölt, amelynek még ispánja is volt. Eredetéről azt tartja, hogy „nyilván egy szláv *bъčarb 'Böttcher; kádár' átvétele”, amely esetleg az oroszból származik, mivel a lexémát a magyarság szomszédságából nem tudjuk kimutatni, az orosz szó korát viszont ismeretlennek mondja. Kevésbé tartja valószínűnek, hogy egy görög szó lenne a forrása, ahogyan az korábban a szakirodalomban felmerült. Megemlíti azt is, hogy ebből a szóból valók a magyar Bocsárd helynevek is, korrigálva a maga korábbi, személynévböl való helynévmagyarázatát. Ezt a helynévfejtést elfogadja KISS LAJOS is, aki a Bocsár és Bocsárd neveket a régi magyar bocsár, bocsárd 'kádár, pohárnok' szóból származtatja, megemlítve, hogy „az Árpád-korban a bocsárok tárolhatták a várszervezet alá rendelt szőlősök által termelt bort” (FNESz.). Régi szótáraink közül egyikben sincs rá vonatkozó adat. KRESZNERICS FERENC és a CZUCZOR-FOGARASI-szótár is csupán helynévként említi.

Árpád- és Anjou-kori személynévi előfordulására nem találtam közvetlen adatot, de az ÁSz.-ban akadnak esetleg ide vonható adatok: 1279: Bolchardus, 1279/1494: Bolchardus, amelyek valószínűleg egy Bolcsárd névalak latinizáló végződéssel ellátott formái (a névben a szóbelseji $l$ megjelenéséhez lásd KATONA 2020: 150-152). KISS LAJOS ide tartozónak mondja az 1211: Bosar személynevet is (FNESz. Karancslapujtó), amely egyedüli előfordulásként szerepel Bosur, Busar nevekkel együtt az ÁSz.-ban. Régi családneveink között kevésbé gyakori előfordulással szerepelnek az erre a tőre visszavezethető formák: elsőként 1522-ben - $i$ képzős Bochari, 1576-ban pedig Bocsárdi alakban fordul elő, ezek azonban a Bocsár Bocsárd helynevekből alkotott személynevek (RMCsSz.). N. FODOR JÁNOSnak a 18. század eleji állapotokat tükröző Történeti magyar családnévatlaszában nem szerepel egyik név sem (TMCsA.). Az újabb kori családnévanyagban HAJDÚnál található ugyan Bocsár családnév, 2007-ben azonban ilyen formában senki nem viselte Magyarországon ezt a nevet, Bócsár-ként is mindössze hárman, de a fenti helynévi alapú Bocsárdi Bocsárdy neveknek is csupán 28 viselője volt, Bocsáry-nak pedig egy embert hívtak akkor (ÚCsnT.)

Településnévként az alábbi adatait ismerjük. 
Bocsár 'település Csanád vm. DNy-i csücskében Torontál vm. határánál; ma Bočar' 1211: Bocar, v. Bogar, v., 1238/1377: Buchar, pr., 1274>1340: Bochar (KMHsz. 1.). GYÖRFFY GYÖRGY szerint várnépek lakták, akiknek pohárnok foglalkozására a település nevéből következtet (Gy. 1: 849).

Bocsár 'település Nógrád vm.-ben, Salgótarjántól Ny-ra; a mai Karancslapujtő része' *1330>1367>XIX: Bocsár (Gy. 4: 231). GYÖRFFY a lakóiról nem közöl semmiféle információt.

Bocsár 'település Abaúj vm. középső részén, Kassától D-re; ma Bočiar' 1249: Boltsschar, t., [1267]: Bolchar, 1332-35/PR.: Belser Boher (Gy. 1: 69). GYÖRFFY szerint várnépek, illetve várjobbágyok lakták, akik foglalkozásáról azonban nem tesz említést. A település neve jóval gyakrabban szerepel $-d$ helynévképzövel ellátott Bocsárd formában (ehhez lásd TóTH V. 2001: 29), a magyar neve ma is ez.

Ezek mellett két Bocsárd nevü településről tudunk az erdélyi Fehér megyében:

Bocsárd 'település Fehér vm.-ben, Gyulafehérvártól É-ÉNy-ra' 1238/12901301: Buchad, 1299/1369/1590: Bwchard, t., v., 1332-35/PR.: Buchard Bulhard $\sim$ Bohard (Gy. 2: 134). Később Borosbocsárd néven szerepel, ez a neve a közeli Búzásbocsárd nevéből következtethetően — esetleg már a (korai) ómagyar korban is meglehetett. A jelzői szerepü névrész minden bizonnyal a település bortermelö jellegére utal. A településnév mikrotoponimákban is előfordul: Bocsárdpataka-fö: 1299/1369/1590: Bwchardpatakafeo, loc. és Bocsárd-mezö: 1299/1369/1590: Buchardmezeo, loc. (Gy. 2: 102, 134).

Bocsárd 'település Fehér vm.-ben, Balázsfalvától ÉNy-ra' 1303: Bochard, amelyet már az ómagyar korban is említenek a ma is használatos Búzásbocsárd formában: 1332-35/PR.: Buzasbuchard Buzabuhhard $\sim$ Buzazbuchard (Gy. 2: 134). Ezek pohárnok foglalkozású lakóira csak nevükböl következtet GYÖRFFY.

Összegzésképpen megállapítható, hogy bocsár köznévröl közvetlen adatunk nincs a korai ómagyar korból, latinizált formában azonban többször is említik a források. Személynévként való használatára az Árpád-korból nagy valószínüséggel van adat, a - $d$ végü formák személynévképzős változatok is lehetnek. Családnévként azonban nem tudjuk adatolni a középkorból, az újkorban is rendkívül ritka előfordulású. Mindez esetleg arra utal, hogy a családnevek kialakulásakor köznévként már nem vagy csak egészen kis területen lehetett használatban. Öt település nevében igazolható a szótő jelenléte, két esetben alapalakban szerepel, két esetben $-d$ helynévképzős formában, egy település nevében pedig mindkét névformában. A képzős formák alapján nem szükséges a közszó $d$-re végződő változatát feltenni (ahogyan KNIEZSÁnál és KISS LAJOSnál láthattuk). A helynevek a Kárpát-medence különböző térségeiben fordulnak elö: Abaúj, Nógrád, Csongrád és az erdélyi Fehér (2) vármegyében (lásd ehhez az 1. térképet). 


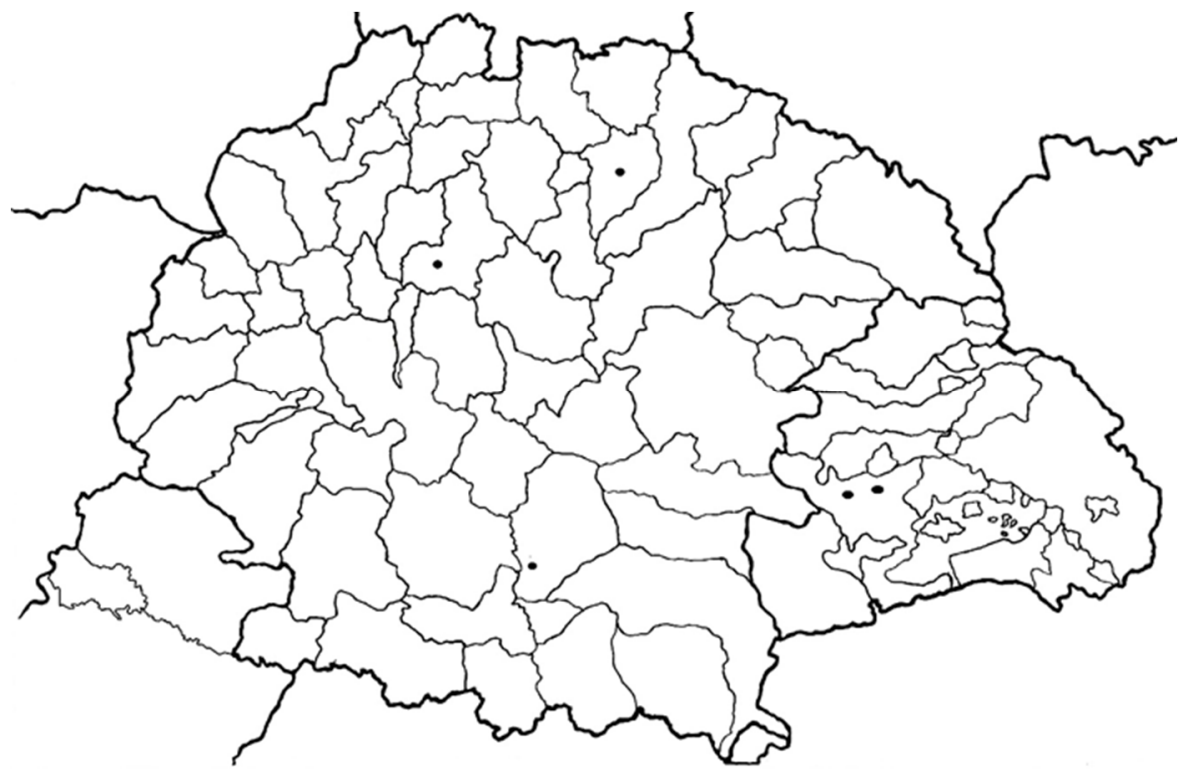

1. térkép. Bocsár településnevek a Kárpát-medencében

3. A kádár 'hordókészítö' a köznyelv szavaként széles körben elterjedt szó. Legkorábbi szótáraink már tartalmazzák, Calepinus szótárában 1585-ben kádár formában szerepel (TESz.). Az Erdélyi szótörténeti tár gazdagon adatolja a szót, első adatát még korábbról közli: 1570: hogy az Kadart Be Idezzek (SzT.). A kádár a régi magyar szótárak közül szerepel SZENCZI MOLNÁR ALBERTnél 'Doliarius, Vietor' (azaz 'hordókészítő, kosárfonó', vö. FINÁLY 1884) jelentéssel. Fontosabb 19. századi szótárainkban a következő jelentésekkel találjuk meg: 'Mesterember, ki kádakat, hordókat, sajtárokat, dézsákat, s több eféle faedényeket készít, máskép: bodnár. Németesen: pintér' $(\mathrm{CzF}$.); 'Kádat, hordót, dézsát készítő mesterember' (BALLAGI).

A szó eredetével kapcsolatban KNIEZSA bizonytalanul nyilatkozik, a kétes eredetű szavak között tárgyalva a köznevet: „Bár a foglalkozást jelentő -arb képző minden szláv nyelvben megvan és a $k a d b$ szó is mindenütt ismeretes, a *kadarb szót csak a sz[lovák]ból és a vendből ismerjük, de ezek lehetnek magyarból való átvételek is" (SzlJsz. 657). A TESz. jóval több szláv nyelvböl adatolja, de feltűnőnek tartja, hogy csak a magyarság szomszédságában van meg. A szó közvetlen forrásának legnagyobb valószínúséggel a szlovént mondja. A vele összefüggésben lévő, a szlávban kétségkívül ennek alapszavaként tekinthető magyar kád is közvetlenül a délszláv nyelvek valamelyikéböl kerülhetett be a magyar nyelvbe (TESz.). Már KNIEZSA is felvetette (korábbi elképzelések nyomán), hogy a kádár esetleg ennek a magyar -ár képzővel alakított változata, de ez a képzésmód a nyelvújítás korára volt jellemzö; ezt az érvelést a TESz. is átveszi, de megjegyzi, hogy a képző régebbi szavakban (pl. solymár) is jelentkezik. 
Személynévként jó néhány adatát ismerjük az Árpád-korból, ezek közül egyesek azonban aligha származhatnak a foglalkozásnévböl. A krónikairodalomban a hun-magyar mondakörben szerepel ilyen nevet viselő személy, Kézainál például 1282-1285: nomine Kadar de genere Turda (ÁSz.) formában. Ezt a nevet később, a 18. sz. végétől köznévként 'egyfajta bíró' értelemben kezdték használni (TESz.). Más esetekben (pl. +1214/1334: Kadar filio Folkus, 1255/1255: Stephanus filius Cadar de Tolchva; ÁSz.) viszont a személynevek mögött nem minden alap nélkül sejthetjük a szláv eredetü foglalkozásnevet. (Az utóbbi név viselője például a híres bortermelő helyről, Tolcsváról való.) Ezt a feltevést erősíti az is, hogy a későbbiekben családnévként meglehetősen gyakori előfordulásúnak mutatkozik, KÁZMÉR MIKLÓS majdnem két hasábnyi adatot közöl erre vonatkozóan (RMCsSz.). 2007-ben Magyarországon 9209 személy viselte ezt a családnevet, HAJDÚ szerint „A nyelvterület keleti felében, Debrecen környékén és északkeleten, de különösen Erdélyben igen gyakori." (CsnE. 235). A fenti, mondákban szereplő nevet HAJDÚ az ótörök eredetü 'hatalmas, erős' jelentésü Qadar Qadïr név átvételének tartja. Úgy véli, a családnév egyrészt ebből alakult apanévi funkción át, másrészt pedig a foglalkozásnévböl, amelyet 16. századi szláv jövevényszónak tekint.

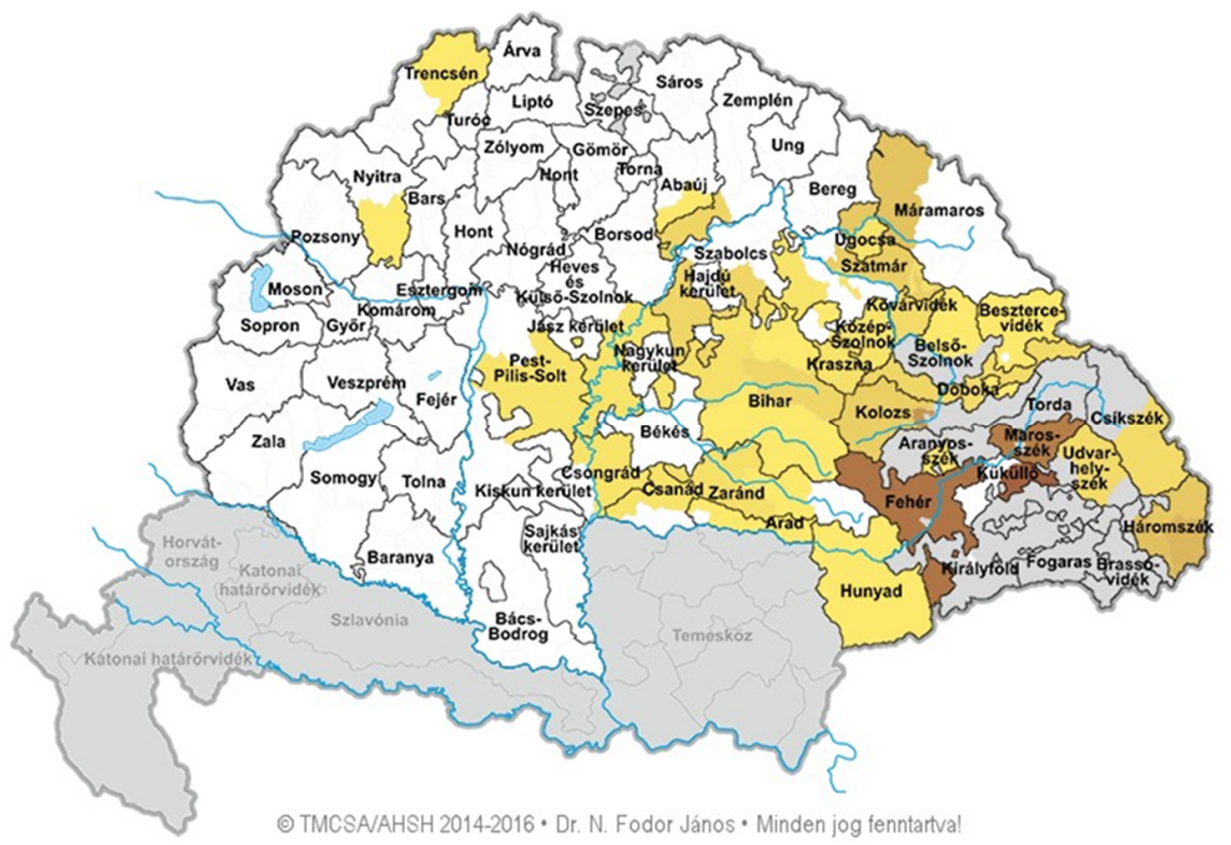

2. térkép. A Kádár családnév gyakorisága 1720-ban

(a sötétebb színek nagyobb gyakoriságot jeleznek)

VÖRÖS FERENC szerint ez utóbbi szó a déli, illetve az északi szláv nyelvekből/ dialektusokból érkezhetett nyelvünkbe, leginkább a szlovák lehetett az átadó. A 
családnév 1720-ban az ország keleti és középső területein volt leginkább elterjedve (2017: 458). N. FODOR JÁNOS történeti családnévatlaszának térképe szerint (lásd a 2. térképen) a 18. század elején Erdély és a Partium területén kívül máshol elszórtan mindössze egy-egy adattal szerepel (TMCsA.).

Helynévként mindössze egyetlen Kádár névről van tudomásom, egy Vas megyei birtokot említenek ilyen néven: 1257: in comitatu Castriferrei ... possessione Kadar vocata (ZalaOkl. 1: 33).

De elképzelhető, hogy Kádár birtoknevet takar az a Bars megyei említés is, amely ezt Szőleny szomszédságában, a Garam mellett levőnek mondja: 1265: particulam terre ... Zeulen vocatam vicinam et commetaneam cum Kadar prope Gran (ÁÚO. 8: 137), ezt azonban az ÁSz. és GYÖRFFY is személynévi előfordulásnak tekinti (Gy. 1: 478).

Felvetődhet még a Veszprém mellett fekvő Kádárta nevének (1355: Kadarta) az ide kapcsolása is. MIKESY SÁNDOR szerint ismeretlen eredetü, mivel „A megfejtésére irányuló eddigi kísérletek nem értek el kielégítő eredményeket." (VHL. 210). KISS LAJOS bizonytalanul a régi Kádár személynévhez kapcsolhatónak tartja, annak -ta képzőbokros származékaként (FNESz.). Jelzi ugyanakkor azt is, hogy „a m. kádár foglalkozásnévhez, illetőleg annak szláv eredetijéhez aligha van köze”.

Noha HAJDÚ 16. századi jövevényszónak mondja (CsnE. 235), a fentiek alapján megállapítható, hogy a kádár közszóként már létezhetett a korai ómagyar korban is: ezt valószínüsíti (gyér számú) személynévi és esetleg (kevésbé valószínüen) helynévi előfordulása is. VÖRÖSnek azt a feltevését, miszerint a jövevényszó a szlovákból került volna be a magyarba, nem támogatja a lexéma családnévként való elterjedtségének a névföldrajza. Ugyancsak ellene szól ez a TESz. szlovén eredeztetésének is. A családnév hiánya a Dunától Ny-ra felveti azt is, hogy az említett helynevek esetleg inkább a nem foglalkozásnévi eredetű személynévből származtathatók. A foglalkozásnévi alapú, szolgáltatónépeket jelölő településnevek közé aligha sorolható be, HECKENAST nem is veszi fel a listájába (1970).

4. A bodnár ma már köznévként elavult, illetve nyelvjárási szó (TESz., ÚMTsz.). Eredeti jelentése 'hordókészitő' volt, vagyis a fentebb tárgyalt bocsár és kádár, illetve a pintér szinonimája lehetett. Később a németből átvett bognár szó hatására megjelent 'szekérgyártó' jelentése is. Közszói használatára elsőként 1584-ből van adatunk: bodnar (TESz.), Szikszai Fabricius Nomenclaturájában is szerepel, 1590: Bodnar (RMGl.). Régi magyar szótáraink közül SZENCZI MOLNÁR ALBERT említi 'Faber materiarius' (a. m. 'famunkás', vö. FINÁLY 1884) általános jelentéssel. PÁPAI PÁRIZnál és KRESZNERICSnél nem található meg, szerepel viszont a más fontos 19. századi szótárakban: 'Kádár, németesen pintér. Szoros értelemben olyan mesterember, ki bodonféle edényeket készít, de szélesebb értelemben hordókat, kádakat, sajtárokat, kannákat és hasonló faedényeket gyártó mesterember' (CzF.), 'Hordókat, faedényeket készítő mesterember, más 
néven kádár, pintér' (BALLAGI). A legújabb tájszótár Heves megye, Karcag, Hajdúböszörmény területéröl és a palóc vidékről adatolja, de butnár alakban közli Moldvából is (ÚMTsz.).

A szó szláv eredetü, megfelelöi megtalálhatók több nyugati, déli és keleti szláv nyelvben is. KNIEZSA szerint a magyarba egy szlovén, ókaj-horvát *bъdnarb kerülhetett át (SzlJsz. 96), ugyanezt vallja némileg bizonytalanul a TESz. is. A szlávban ez a *bъdbnъ fönévnek az *-arjb foglakozásnévképzős származéka. Az alapszó bodon > bödön formában ugyancsak átkerült a magyarba. A bodnár szónak a magyarban többféle hangalakváltozata is létrejött: bonnár, bënnár, a régiségben: bondor (TESz.). Az EtSz. szerint a magyar bodnár közvetlen forrása a szláv bedna(á)r lehet.

Árpád- és Anjou-kori személynévi előfordulására nem találtam adatot. Családnévként viszonylag gyakori lehetett viszont már a középkorban is, KÁZMÉR MIKLÓS majdcsak egy hasábnyi adatot közöl erre vonatkozóan, először 1406-ban fordul elö Bodnar alakban (RMCsSz.). VÖRÖS FERENC szerint az 1720-as években jellemzően az ország északi területein volt használatos Bodnar $\sim$ Bodnár Bondár Bodnyar alakváltozatokban. Úgy véli, hogy a szó valószínüleg az északi szláv dialektusok közvetítésével került a magyarba, a magyar Bondár hangátvetéses változatai pedig a keleti szláv nyelvekben vagy azok hatására alakulhattak ki (2017: 392). N. FODOR JÁNOS térképei (TMCsA.) a 18. század elején az ország középső, valamint északkeleti és északnyugati részein mutatják a családnév jelenlétét, a nem túl nagyszámú név egy harmada Zemplén megye területéről való. A családnévatlasz megfelelö térképén feltünő a név különösen gyakori jelenléte a tokaji borvidék környezetében (lásd a 3. térképen). 2007-ben 14.943 személy viselte Magyarországon a nevet, többféle alakváltozatban, pl. Bonnár, Bondár, Bondar. HAJDÚ MIHÁLY szerint „Általában az Alföldön, leginkább annak északkeleti részén, Szabolcsban, Szatmárban, de Békés megyében is: Sarkadon és környékén gyakori." (CsnE.). Abból, hogy a 19. században névmagyarosításkor sokan választották a Bodnár családnevet, HAJDÚ arra következtet, hogy akkoriban még élhetett a szó közszói jelentése is. VÖRÖS FERENC a 2009-es adatok alapján az országban való elterjedtségéről a következőket mondja: legjellemzőbb Borsod-Abaúj-Zemplén megyében (4044 fö), ezt követi Szabolcs-Szatmár-Bereg megye (2606 fö), Budapest (1983 fö), Hajdú-Bihar megye (1832 fö), Pest megye (1125 fö), Békés megye (606 fö). Azt láthatjuk tehát, hogy döntően az ország keleti területein, illetve Pest megyében gyakori ez a családnév (2014: 250).

A foglalkozásnév a mai nyelvjárások szük térségében fordul elö. A névföldrajzi adatok szerint régebben jóval nagyobb területen ismerhették a szót, annak aktív ismerete nélkül ugyanis aligha alakulhatott volna belőle viszonylag gyakori családnév. A névföldrajzi ismeretek kevésbé támogatják KNIEZSA és a TESz. szlovén, horvát eredeztetését, sokkal inkább a magyar nyelvtől északra, északkeletre elhelyezkedő szláv nyelvek átadó szerepét valószínüsítik. 


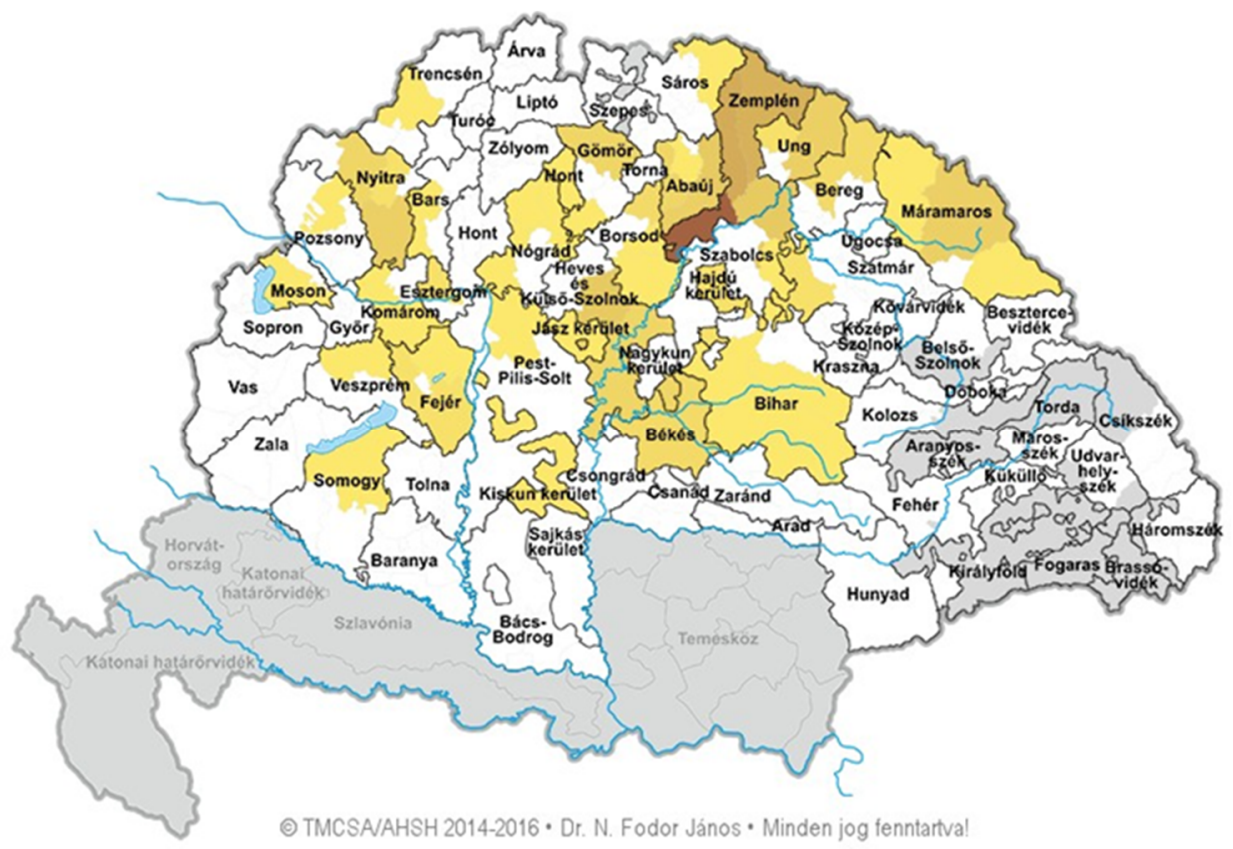

3. térkép. $A$ Bodnár családnév gyakorisága 1720-ban (a sötétebb színek nagyobb gyakoriságot jeleznek)

5. A pintér - a bodnár-hoz hasonlóan — köznévként elavult szó, nyelvjárási lexémaként azonban ma is többfelé előfordul. Eredeti 'hordókészitő' jelentése mellett más értelemben használják Jánosiban (Szlovákia) és Gyöngyös környékén, itt 'disznóölésre vállalkozó, ehhez értő, de a hentesmesterségben többnyire nem szakképzett férfi; böllér' jelentésben él (ÚMTsz.). Összetételei (pintér(ezö)gyékény, pintérkákó, pintérlelke) az eredeti jelentéséhez kapcsolódnak. Újabb kori köznévi adatai föleg a Dunántúl nyugati részéröl valók, de szerepelnek mellettük Szeged környéki előfordulások is. Első közszói említését a TESz. szerint a Margit-legendából ismerjük (1510: pinter), de MOLLAY jóval korábbi előfordulásait is említi: Selmecbányáról 1365-ből (Pinter), Sopronból 1379-ből (pinter), továbbá szóeleji $b$-vel közli a szász telepítésü felvidéki Bártfáról és az erdélyi Brassóból a 15. századból (1982: 439). A 16. századi szójegyzékek is tartalmazzák (RMGl. 573). Régi szótáraink közül SzENCZI MOLNÁR ALBERTnél a kádár értelmével megegyezően 'Doliarius, Vietor' jelentéssel található meg, ugyanígy szerepel később KRESZNERICSnél is. Két szótári értelmezése a 19 századból: 'Fából dolgozó kézmives, ki hordókat, kádakat, bödönyöket, s hasonló fa edényeket készít; s néha, kivált az uraságok, kolostorok, borkereskedők szolgálatában levén, borokat is kezel. Eredetileg német szó: Binder; magyarul kádár, vagy bodnár, mely ugyan szükebb értelmü mint Binder, mivel nem csupán kádakat, illetőleg 
bodonokat készít' (CzF.), 'Hordókat, kádakat és más faedényeket készítő iparos' (BALLAGI).

A foglalkozásnév bajor-osztrák eredetü. A német binden 'köt, megköt, összeköt, valamit valamivel körülvesz, körülköt stb.' ige fönévi származéka (középfelnémet: Binder), amely azért válhatott a hordókészítő mesterember jelölőjévé, mert a hordókészítés munkamenetében igen fontos mozzanat a dongák összeabroncsozása, abronccsal való összekötése (TESz.). A lexéma zöngétlen $p$ és $t$ hangjai utalnak a magyar szó bajor-osztrák eredetére, amely MOLLAY szerint pontosabban korai újfelnémet kori hazai bajor-oszták eredetủ (i. h.).

Árpád-kori személynévi előfordulását nem ismerjük. A TESz. első személynévi említéseként kérdőjellel egy 1406-os pyter [っ: pynter] adatot közöl. Régi családnévszótárunk meglehetősen gyakorinak mutatja, több mint egy hasábnyi adatot találunk KÁZMÉRnál, első előfordulásai a 15. század elejéről valók (1414: Pyther, 1419: Pynther, RMCsSz.). VÖRÖS FERENC családnévatlasza szerint az 1720-as években leginkább az ország nyugati területein gyakori (2017: 352). N. FODOR JÁNOS családnévatlasza (TMCsA.) a 18. század elejéről csaknem háromszáz Pintér családnevet tartalmaz, amelynek több mint egyharmad része Vas és Sopron megyéből való. A név döntően a Dunántúlon szerepel, elterjedése lényegében nem lépi át a Tiszát, és nem terjed ki az ország északi térségére sem (lásd a 4. térképen).

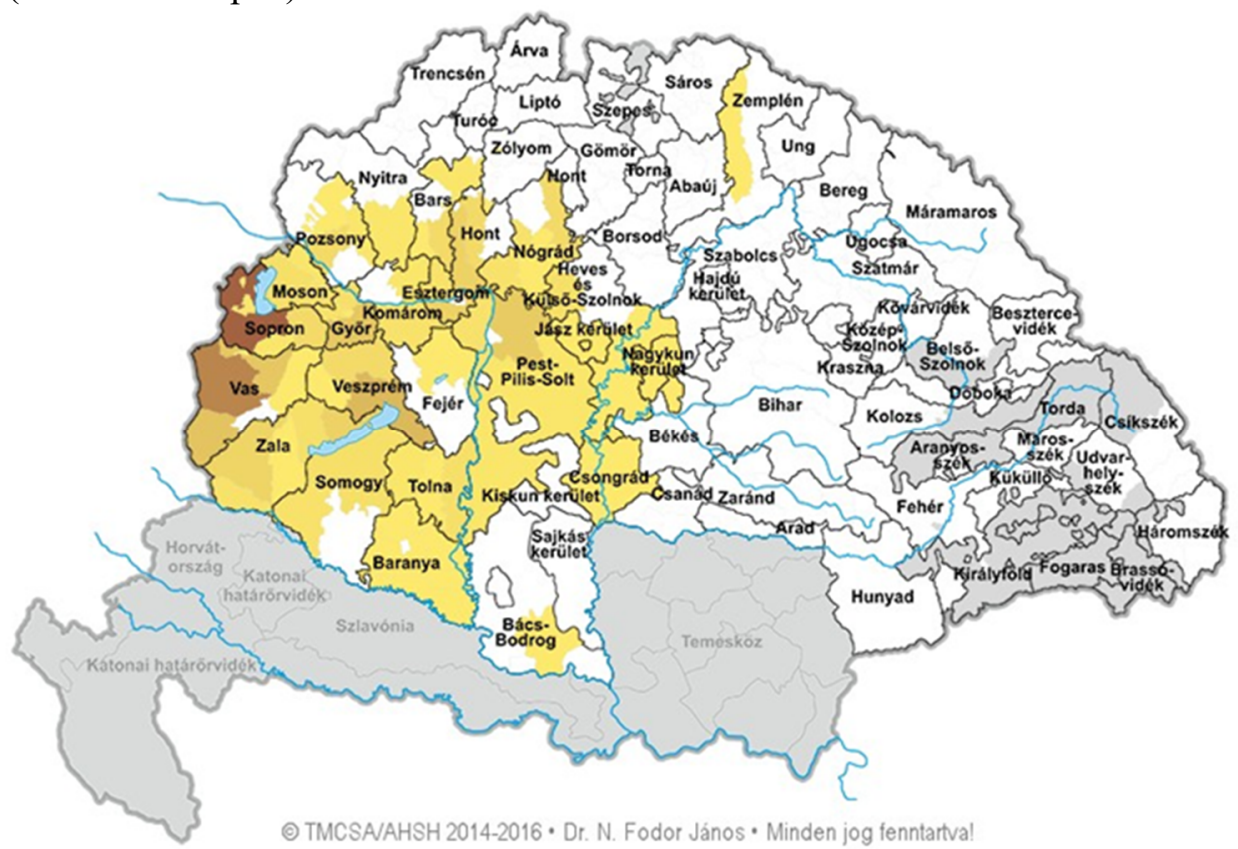

4. térkép. A Pintér családnév gyakorisága 1720-ban

(a sötétebb színek nagyobb gyakoriságot jeleznek) 
A Binder mint német név Brassó és Beszterce vidékén szerepel. 2007-ben csaknem 25 ezer ember viselte Magyarországon ezt a nevet, így a gyakoribb magyar családnevek közé tartozik. HAJDÚ szerint a Dunántúl nyugati részén és a Délvidéken gyakoribb (CsnE.).

Pintér településnévről nincs tudomásom.

A nyelv- és névföldrajzi adatok azt mutatják, hogy a jövevényszó nyugat felöl, a német-magyar nyelvhatár irányából terjedhetett el a magyar nyelvterületen. Az Árpád-kori jelentősebb német telepítések környezetében nem szerepel, ott névként is csak a Binder változatáról van tudomásunk, amely a helyi német nyelv elemeként értelmezhető.

6. A kádas melléknév, illetve főnév a kád főnév -s melléknév-, illetve főnévképzős származéka. A TESz. szerint a kád szláv, közelebbről déli szláv, leginkább szlovén eredetű szó a magyarban, amely valójában nemzetközi vándorszó, s végső forrása a héber kad 'faveder' (TESz.). A kád első köznévi adata a 14. sz. végéről, a Besztercei szójegyzékből való: 1395 k.: kad (RMGl.). A szó eredeti jelentése 'fából készült, nagy ürtartalmú, felül nyitott edény' (TESz.).

A kádas fönévi származék legkorábbi előfordulásait szótáraink személynévi használatban közlik, első közszói előfordulását 1574-ből ismerjük (kadasoknak, TESz.). Jelentését — olykor csak kérdőjellel — 'kádár, pintér' értelemben adják meg (OklSz.), de 'egy fajta kiskereskedő'-ként is szerepel. Régi szótárainkban csupán ERDÉLYI FERENC említi ugyancsak kérdőjellel 'kádár, pintér' jelentéssel (SzT.). Tájszóként közli a Szegedi és a Szlavóniai tájszótár (SzegSz., SzlSz.). A SzT. sem említi közszóként.

Árpád-kori személynévi előfordulására nem találtam adatot (ÁSz.). KÁZMÉR MIKLÓS viszont majdcsak egy hasábnyi adatot közöl róla, első előfordulásaként egy 1470-ből való Kadas személynevet ad meg (RMCsSz.). Az alapjául szolgáló főnév fö jelentését 'kádár, pintér'-ként határozza meg, de emellett szerepel nála a 'salétromfőző', illetve a 'füszert áruló kereskedő' értelem is. N. FODOR JÁNOS történeti családnévatlasza (TMCsA.) mindössze 10 ilyen nevet tüntet fel, amelyek az ország északkeleti részéből valók. 2007-ben Magyarországon több mint ezer személy viselte ezt a családnevet, az ország keleti részén. HAJDÚ szerint a név a 'kádkészítő, kádgyártó' jelentésü foglalkozásnévből való, de felmerül annak a lehetősége is, hogy a Kádas egy ótörök Qadar név átvételének a magyarban megrövidült és $-s$ kicsinyítő képzővel alakult formája (CsnE.). Ez utóbbi feltevés azonban kevésbé támasztható alá.

A kádas településnévi előfordulására nem találtam adatot, szerepel azonban melléknévként mikrotoponimákban (SzT.).

7. A hordós szót fônévi értelemben nem tudom adatolni. Személynévi elfordulása alapján azonban arra következtethetünk, hogy a lexéma egykor fönévként is használatban lehetett. KÁZMÉR MIKLÓS 13 idetartozó adatot közöl, melyek közül 
az első az 1513-ból való Hordos személynév. Ennek közszói jelentését 'kádár, bodnár' értelemben adja meg (RMCsSz.). A történeti családnévatlasz mindössze 12 ilyen nevet tüntet fel, amelyek kizárólag a Dunántúlról valók (TMCsA.). 2007ben Magyarországon csaknem hétszáz személy viselte a Hordós(i) családnevet (ÚCsnT.).

A hordós főnév a hordó 'főleg bor tárolására szolgáló hengeres faedény' fönév $-s$ képzős származéka, amely éppúgy alakulhatott foglalkozást jelentő lexémává, mint a fentebb bemutatott kádas a kád szóból. Maga a hordó származékszó, a hord folyamatos melléknévi igenevének fönevesülése, amelyet a 14. század végétől tudunk adatolni (TESz.).

A hordós településnévi előfordulására nem találtam adatot, szerepel azonban melléknévként mikrotoponimákban (SzT.).

8. A szómező elemeiről összegzésképpen az alábbiakat állapíthatjuk meg.

Kétségtelen, hogy a magyarság már az ösmagyar korban is ismerte a borkészítés mesterségét, erre utalnak az ősmagyar kori ótörök jövevényszavak közül az alábbiak: szölö, bor, seprő (a borkészítés szavaként), szür (ige) (ZSILINSZKY 2003: 202). A nomadizáló életmód miatt is különösen fontos lehetett a bor tárolására szolgáló tartály, amelynek régi magyar megnevezését nem ismerjük. Nem lehetetlen azonban, hogy ezt már akkoriban is a hordó szóval jelölték meg: az ugor eredetủ hord ige (TESz.) melléknévi igenévi származéka egy (bor)hordó edényféle szerkezetböl jelentéstapadással főnevesülhetett (vö. TESz.). Az ezt készítő mestert megnevező korabeli lexémáról sincsenek ismereteink. Az adatok későbbi ritkaságából következtethetően kevésbé valószínü, hogy ez a hordós lett volna, bár a szóalkotás módja alapján ez nem zárható ki. Későbbi főnévi adatolatlansága, illetve családnévi ritkasága mindemellett jelezheti a szó lassú kihalási folyamatát is (ahogyan ez megtörtént más ősmagyar kori, akár az alapszókincsbe tartozó, ősi eredetủ szavakkal is; lásd pl. a 'folyó' értelmü egykori jó szavunkat).

Az ómagyar korban kétségkívül több szó jelölte a magyar nyelvben a hordókészítő mesterembert, amit e nyelvi elemek adatolása kétségkívül igazol. Ezek között biztosan kimutatható három szláv eredetủ elem (bocsár, kádár, bodnár), egy német eredetü lexéma (pintér), és feltehető két belső keletkezésü származékszó (kádas, hordós) megléte is.

A szláv jövevényszavak közül legrégebbi a bocsár lehet, amely több településnévben is szerepel alapalakban, illetve helynévképzős formában. Közszói adatát csak latinizált formában ismerjük, és személynévként sem lehetett gyakori, különösen feltünő családnévi ritkasága. A helynévi formák átvételének koraiságára utalhatnak, mivel a szolgálónépeket megjelölő helynevek a magyar településnevek legrégebbi rétegébe tartozhatnak (HOFFMANN-RÁCZ-TóTH 2018: 290). Közelebbi szláv forrását nem tudjuk meghatározni, feltételezett orosz eredetét különösebb érvek nem támasztják alá. Helynévként a Magyar Királyság középső 
és keleti részén szerepel. Közszói használata a szómező más, a magyar nyelvbe bizonyára később bekerült elemeinek hatására fokozatosan visszaszorult: már a családnevek kialakulásának idején, a 13-15. században sem lehetett széles körben ismert, ma pedig már kihalt szó.

A kádár valószínüleg későbbi szláv átvétel lehet, de semmiképpen sem a 16. századból való. Meglehetett a magyarban már a korai ómagyar korban is, amit elsősorban személynévi adatai hitelesítenek, bár ezek között más előzményre visszamenő nevek is lehetnek. Családnévként való elterjedtsége a 18. század elején Magyarország keleti-északkeleti részére volt jellemző, ami arra utalhat, hogy a családnevek, illetve a családnévelőzmények kialakulásának az időszakában, a 13-15. században tájszóként létezhetett ezen a vidéken. Ez kevésbé valószínüsíti feltételezett szlovén eredeztetését, szlovák származtatása viszont elképzelhető, de gondolhatunk esetleg keleti szláv kapcsolatára is. Később válhatott köznyelvi szóvá. A néhány dunántúli településnévi előfordulása inkább talán a vele homonim korai ómagyar kori személynévre vezethető vissza.

A bodnár lexéma magyar nyelvbeli szerepe a régiségben némileg hasonlóságot mutat a kádár szóéval. Személynévi adatai arra engednek következtetni, hogy ez is része volt a magyar nyelvnek már a korai ómagyar korban is, és a kádárénál akár szélesebb körü is lehetett a területi elterjedtsége. Később kerülhetett be a magyar nyelvbe, mint a bocsár: erre abból következtethetünk, hogy helynevekben nem fordul elö. Névföldrajzi adatai nem támogatják szlovén vagy horvát eredeztetését, kapcsolatai inkább a nyugati, esetleg a keleti szláv nyelvek felé mutatnak. Foglalkozásnévi alkalmazása visszaszorult a magyar nyelvben, de nyelvjárási szóként ma is létezik, használatát azonban befolyásolta a szintén foglalkozásnévi jelentésü, német eredetü bognár szavunk.

A pintér, amely a német nyelvböl került a magyar nyelvbe, ugyancsak része lehetett már a korai ómagyar kori nyelvnek is, de helynévi előfordulásának hiánya nem túl korai átvételre utal. Nyelvföldrajzi adatai azt mutatják, hogy a nyugati magyar-német nyelvhatáron kerülhetett be a magyar nyelvbe, a német betelepítések kevésbé játszhattak szerepet e folyamatban. Tájszóként használhatták, mára kevés helyen ismert nyelvi elemmé szorult vissza.

A kádas és a hordós belső keletkezésű foglalkozásnevek keletkezési koráról nincsenek ismereteink. A családnevek kialakulásának korában nagy valószínüséggel területi megoszlás lehetett közöttük: a kádas a nyelvterület keleti részén volt használatban, a hordós pedig a Dunántúlon. Ma egyik sem él foglalkozásnévként a magyar nyelvben.

A fenti komplex elemzés rávilágított egyfelöl a vizsgált szavak kronológiai viszonyaira, amelyet közszói, helynévi és személynévi előfordulásaikból, illetve ezek hiányából következően vázolhattunk fel. Területi viszonyaikra leginkább személynévi adataikból következtethettünk, amely alapján etimológiai eredetük pontosítására is lehetőség nyílott. 


\section{Irodalom}

ÁSz. = FEHÉRTÓI KATALIN 2004. Árpád-kori személynévtár. 1000-1301. Budapest, Akadémiai Kiadó.

ÁÚO. = Árpádkori új okmánytár I-XII. Közzé teszi WeNZEL GuSZTÁv. Pest (később Budapest), 1860-1874.

BALLAGI MóR 1873. A magyar nyelv teljes szótára, melyben az egyes szók különbözö értelmeinek körülírás általi szabatos meghatározásán kívül különös figyelem van fordítva azoknak szójárásos, közmondási, irodalmi stb. használatára, valamint a szaktudományi és iparbeli müszókra is 1-2. Pest, Franklin Társaság. Hasonmás kiadás: Budapest, Nap Kiadó, 1998.

CzF. = CZuCZOR GERGELY-FogARASI JÁNOS 1862-1874. A magyar nyelv szótára. Pest, [később Budapest], Magyar Tudományos Akadémia.

CsnE. = HAJdÚ MiHÁLY 2010. Családnevek enciklopédiája. Leggyakoribb mai családneveink. Budapest, Tinta Könyvkiadó.

EtSz. = GOMBOCZ ZOLTÁN-MELICH JÁNOS 1914-1930. Magyar etymologiai szótár . Budapest, Magyar Tudományos Akadémia.

FinÁly HENRIK 1884. A latin nyelv szótára. Budapest, Magyar Irod. Intézet és Könyvnyomda.

FNESz. = KISS LAJOS 1988. Földrajzi nevek etimológiai szótára I-II. Negyedik, bövített és javított kiadás. Budapest, Akadémiai Kiadó.

Gy. = GYÖRFFY GYÖRGY 1963-1998. Az Arpád-kori Magyarország történeti földrajza $I-I V$. Budapest, Akadémiai Kiadó.

GYÖRFFY GYÖRGY 1972. Az Árpád-kori szolgálónépek kérdéséhez. Történelmi Szemle 15: 261-320.

HeCKeNAST GuSZTÁv 1970. Fejedelmi (királyi) szolgálónépek a korai Árpád-korban. Budapest, Akadémiai Kiadó.

HOFFMANN ISTVÁN-RÁCZ ANITA-TÓTH VALÉRIA 2018. Régi magyar helynévadás. A korai ómagyar kor helynevei mint a magyar nyelvtörténet forrásai. Budapest, Gondolat Kiadó.

Katona Csilla 2020. Fonotaktikai szerkezetet módositó hangváltozások az ómagyar korban. Debrecen, Debreceni Egyetemi Kiadó.

KIS PÉTER 2010. A királyi szolgálónépi szervezet a 13-14. században. Szegedi Középkortörténeti Könyvtár 25. Szeged. Szegedi Középkorász Műhely.

KMHsz. $=$ HofFMANN IsTVÁN szerk. 2005. Korai magyar helynévszótár 1000-1350. I. Abaúj-Csongrád vármegye. A Magyar Névarchívum Kiadványai 10. Debrecen, Debreceni Egyetem Magyar Nyelvtudományi Tanszéke.

KRESZNERICS FERENC 1831. Magyar szótár gyökérrenddel és deákozattal 1-2. Buda. KRISTÓ GYULA 1976. Szempontok korai helyneveink történeti tipológiájához. Acta Historica Szegediensis. Tomus LV. Szeged.

Mollay KÁROLY 1982. Német-magyar nyelvi érintkezések a XVI. század végéig. Budapest, Akadémiai Kiadó. 
OklSz. = SzAMOTA ISTVÁN-ZOLNAI GyUlA 1902-1906. Magyar oklevél-szótár. Pótlék a Magyar Nyelvtörténeti Szótárhoz. Budapest, Magyar Tudományos Akadémia.

PÁPAI PÁRIZ FERENC 1708. Dictionarium Latino-Hungaricum, succum \& medullam purioris Latinitatis, ejúsque genuznam in Lingvam Hugaricam conversionem, ad mentem \& sensum proprium scriptorum Classicorum, exhibens: Indefesso $X V$. Annorum labore, subcisivis ab ordinariis negotiis, temporibus collectum, \& in hoc Corpus coactum. Leutschoviae, 1708. (Következik külön czímlappal: Dictionarium Hungarico-Latinum, olim magnâ curâ à Clarissimo viro Alberto Molnár Szentziensi collectum; Nunc vero revisum, \& aliquot vocabulorum, in Molnariano desideratorum, millibus Latinè redditis locupletatum. Leutschoviae, 1708.) Újabb kiadások: Nagyszombat, 1762. Szeben és Pozsony, 1767, 1772, 1801.

RÁCZ ANITA 2015. A foglalkozásnévi eredetü településnevek történeti tipológiai sajátosságai. In: BÁRTH M. JÁNOS-BODó CsAnÁD-Kocsis ZsuZSANNA szerk. $A$ nyelv dimenziói. Tanulmányok Juhász Dezsö tiszteletére. Budapest, ELTE BTK Magyar Nyelvtörténeti, Szociolingvisztikai, Dialektológiai Tanszéke. 410-421.

RMCsSz. = KÁZMÉR MIKLÓS 1993. Régi magyar családnevek szótára (XIV-XVII. század). Budapest, Akadémiai Kiadó.

RMGl. = BERRÁR JOLÁN-KÁROLY SÁNDOR szerk. 1984. Régi magyar glosszárium. Szótárak, szójegyzékek és glosszák egyesitett szótára. Budapest, Akadémiai Kiadó.

SzegSz. = BÁlint SÁNDOR 1957. Szegedi szótár. Budapest, Akadémiai Kiadó.

SZENCZI MOLNÁR ALBERT 1611. Lexicon Latino-Graeco-Hungaricum: summa diligentia collectum, adauctum et nunc recens excusum, in quo \& propria nominapro studiosis orthographiae Graece sunt expressa, \& appellativis synonyma Graeca passim inspersa sunt non pauca: vocibusvero positione \& diphthongis carentibus, subjecti sunt versus veterum poetarum, quantitates syllabarum indicantes. Hanoviae.

SzlJsz. = KNIEZSA ISTVÁN 1955. A magyar nyelv szláv jövevényszavai. I/1-2. Budapest, Akadémiai Kiadó.

SzlSz. = PENAVIN OLGA 1978. Szlavóniai (kórógyi) szótár. Újvidék, Forum Könyvkiadó Intézet.

SzT. = SzABÓ T. ATTILA szerk. 1967-2014. Erdélyi magyar szótörténeti tár I-XIV. Bukarest-Budapest, Kriterion-Akadémiai Kiadó.

TESz. = A magyar nyelv történeti-etimológiai szótára I-III. Föszerk. BENKÖ LORÁND. Budapest, Akadémiai Kiadó, 1967-1976.

TMCsA. = N. FODOR JÁNOS Történeti magyar családnévatlasz. https://csaladnevatlasz.hu.

TÓTH VALÉRIA 2001. Az Árpád-kori Abaúj és Bars vármegye helyneveinek történetietimológiai szótára. A Magyar Névarchívum Kiadványai 4. Debrecen, Debreceni Egyetem Magyar Nyelvtudományi Tanszék.

TÓTH VALÉRIA 2019. Módszertani problémák a Kárpát-medence régi helyneveinek etimológiai kutatásában. Helynévtörténeti Tanulmányok 15: 21-48. 
ÚCsnT. = HAJDÚ MiHÁLY 2012. Újmagyarkori családneveink tára. XVIII-XXI. század. I. Adatok. Budapest, Szerzői kiadás.

ÚMTsz. = B. LŐRINCZY ÉVA. főszerk. 1979-2010. Új magyar tájszótár I-V. Budapest, Akadémiai Kiadó.

VHL. = ILA BÁLINT-KOVACSICS JÓZSEF 1964. Veszprém megye helytörténeti lexikona. Budapest, Akadémiai Kiadó.

VÖRÖS FERENC 2014. Kis magyar családnévatlasz. Pozsony, Kalligram.

VÖRÖs FERENC 2017. Kárpát-medencei történeti családnévatlasz. Pozsony, Kalligram.

ZalaOkl. = NAGY IMRE-VÉGHELY DEZSÖ-NAGY GYULA szerk. 1886. Zala vármegye története. Oklevéltár 1. Budapest.

ZSILINSZKY ÉvA 2003. Szókészlettörténet. [Az ösmagyar kor.] In: KISS JENÖPUSZTAI FerenC szerk. Magyar nyelvtörténet. Budapest, Osiris Kiadó. 173-203.

\section{Bocsár and Similar Names}

In my paper I study a characteristic type of social group names that designate a group of people, human communities even in a nominative form. During the Middle Ages the inhabitants of a settlement or a part of the population were obliged to perform some kind of a service and the word designating the individual came to be used as the name of the entire village. This settlement name type is referred to as a settlement name with an occupational name origin. I examined this topic from the perspective of historical onomastics and linguistics, as this issue has not yet been studied in scholarly research projects. My work is based on the methodology applied by VALÉRIA TÓTH in an earlier paper (2019) in which she provided a comprehensive analysis of the name cluster of the Csatár and Teszér settlement names and I extended her method to the Bocsár settlement names. I focused on Bocsár and lexemes that have the same meaning of 'barrel maker', including the kádár, bodnár, pintér words which also have records in the Old Hungarian Era. I started out not from the toponymic occurrence but the semantic identity that is present besides a degree of formal similarity (similar word endings). Besides these, I also provide an analysis of the kádas and hordós words.

My research has revealed that the barrel makers were probably designated in the Old Hungarian Era by the Slavic bocsár, kádár, bodnár, the German pintér, as well as the kádas and hordós words that were created internally. Of the Slavic loan words, the oldest one could be bocsár, which appears in several settlement names in base form as well as with a topoformant. We are familiar with its common noun record only in Latinized form, it could not be frequent as a personal name, and its use as a family name is especially rare. Kádár is probably a later instance of borrowing from Slavic, it is certainly not from the $16^{\text {th }}$ century. It could be present in Hungarian already in the early Old Hungarian Era, which is confirmed mostly by its anthroponym data, even though there may also be names with other 
antecedents. The few occurrences as a settlement name in the Transdanubia region may originate from the early Old Hungarian Era anthroponym that is homonymous with it. The role of the bodnár lexeme in Hungarian language somewhat resembles that of the word kádár in historical times. Its anthroponym data indicate that it was part of the Hungarian language in the early Old Hungarian Era already and its territorial prevalence could be more extensive than that of kádár. Its use as an occupational name became less frequent in Hungarian but it still exists as a dialectal word today, however, its use was influenced by the word bognár of a German origin and having the same meaning. Pintér could also be part of language in the early Old Hungarian Era but the lack of its occurrence as a toponym indicates not too early borrowing. It could be used as a dialectal word and by now it is a linguistic element known at only a few places. We have no information about the age of the creation of the kádas and hordós words. At the time when family names emerged most probably they were characterized by territorial distribution: kádas was used in the eastern part of the language area, while hordós was used in Transdanubia. Today, none of these appear as occupational names in Hungarian. The complex analysis presented has shed light on the chronological features of the examined words that were outlined based on their occurrences (or the lack of them) as common nouns, toponyms, and personal names. Conclusions about their territorial features could mostly be made based on their anthroponym data, which also enabled the specification of their etymological origin. 